\title{
Identifying Microscopic Understanding of Chemistry Education Students and Its Relationship with Multiple Intelligences and Learning Style
}

\author{
Atiek Winarti \\ Chemistry Education Department \\ Lambung Mangkurat University \\ Banjarmasin, Indonesia \\ atiekwin_kimia@unlam.ac.id \\ Iriani Bakti \\ Chemistry Education Department \\ Lambung Mangkurat University \\ Banjarmasin, Indonesia
}

\author{
Almubarak \\ Chemistry Education Department \\ Lambung Mangkurat University \\ Banjarmasin, Indonesia
}

\begin{abstract}
The study aimed to identify microscopic comprehension, multiple intelligences, and learning style of Chemistry Education Department students, as well as to investigate the relationship among multiple intelligences, learning style, and microscopic comprehension. The descriptive correlation study was the method applied in this research. The sample consisted of 277 Chemistry Education Department students of Universitas Lambung Mangkurat (ULM). Microscopic Comprehension Conceptual Test (MCCT), Multiple Intelligences Test (MIT) and Learning Style Test (LST) were used as the instruments of the research. Data analysis techniques used percentage and correlation coefficient of Pearson Product Moment. The results showed that (1) The ability of Chemistry Education Department students to understand the microscopic concept can be categorized as good and sufficient, (2) Mostly dominant multiple intelligences of the students are intrapersonal, interpersonal, naturalistic and kinesthetic. Only a few students who have dominant intelligence in Linguistic and mathematical logic, (3) Most of the students have auditory and kinesthetic learning style, (4) There is positive relationship between multiple intelligences and microscopic comprehension, (5) There is weak relationship between visual together with auditory learning style and microscopic comprehension, and (6) The relationship between kinesthetic and microscopic comprehension do not exist.
\end{abstract}

Keywords-microscopic comprehension, multiple intelligence, learning style.

\section{INTRODUCTION}

Instructional strategies currently applied at all educational levels are still mass. Treatment and educational services provided to all students are the same, even though students differ in many respects, both auditory and kinesthetic learning styles, level of skill, intelligence, interests, talents, and creativity. The strategy of educational services like this is appropriate in terms of equal opportunity, but less support efforts to optimize the development potential of learners appropriately.
Among factors influencing the differences in learners' characteristics, learning styles and intelligence are two factors that need to be considered. Learning style is a combination of how people absorb information and then organize and process it. Learning style is a distinctive characteristic of the person and also determines how a person's learning. According to [1] student learning styles can be used as a reference for the teacher to select appropriate teaching methods. The intelligence refers to the ability or mental capacity to think. According to [2], a person's intelligence is not only shown by a high IQ score. IQ measures two kinds of intelligence namely linguistic and mathematical logic only, meanwhile, every human has eight kinds of intelligence. It refers to as multiple intelligences.

Research studies conducted by [3] and [4] showed that there is a significant positive relationship between learning style and student achievement in the subjects of Chemistry and Mathematics. Ref. [5] also found that there is a positive relationship between multiple intelligences and student achievement in physics. The most influencing learning style on mathematics achievement is visual learning, while in chemistry, the most influencing learning style is independent. In case of multiple intelligences, it is discovered that learning achievement of physics is influenced by multiple intelligence with a fairly high correlation coefficient of $0.571 \%$.

Based on the results of the previous studies, it was known that teacher teaching strategies affected by student's learning style. Ref. [6] stated that learning styles could predict the teaching method. That is why the information about student's learning style is very important for the teaching plan because by knowing student's learning style, the teaching methods will be easier planned. Based on the findings of this study, it can be concluded that these two learning styles and multiple intelligences contribute to students' achievement. Both the learning styles and multiple intelligences can affect teachers' lesson plans. The implementation of these aspects have implications on the individualization of instruction. On the one 
hand, teaching strategies must be adapted to the multiple intelligences and learning styles of most of the students, on the other hand, it must consider several intelligences and learning styles of each student.

Viewed from the characteristics of chemical concepts which mostly consist of abstract mathematical concept, it can be predicted that there is a relationship between achievement in chemistry with multiple intelligences and learning styles. Abstract concepts are usually understood by those who have visual-spatial intelligence, while the complex mathematical concepts will be understood by those who have a logicalmathematical intelligence [7]. In learning chemistry, microscopic comprehension concept is very important because almost all of the concepts are microscopic. The microscopic comprehension concept will support the comprehension of the entire concept.

This study intends to identify microscopic comprehension of chemistry concepts and learning styles of chemistry education students. It also evaluates the relationship between microscopic comprehensions and multiple intelligences as well as learning styles. By knowing students of microscopic comprehension about chemistry concepts, multiple intelligences, and learning styles, learning strategies that will improve students' achievement can be planned easily.

\section{METHODS}

This research is descriptive correlation. The sample of the study was all students of Chemistry Education FKIP Universitas Lambung Mangkurat consisting of 277 students. The research instruments used were (1) Microscopic comprehension Test on several materials of High School Chemistry Course such as Acid-Base, Chemical Bonding, and Chemical Equilibrium; (2) Multiple Intelligences Test (MIT) developed by Armstrong (2014), and (3) Learning Styles Test (LST) developed by Babich, Burdine, Albright, and Randol, (1976) at Murdoch Teachers Center Wichita, Kansas. LST can be accessed online at file://C:/Users/User/AppData/Local/Temp/CITELearningStyle sInstrument.pdf/. Data analysis used percentage technique and statistical by Pearson correlation coefficient product moment.

\section{RESULTS AND DISCUSSION}

\section{A. Microscopic Comprehension of Chemistry Education Students}

Microscopic Comprehension of Chemistry Education Students can be viewed as follows in Table I.

Most of the students' comprehension of microscopic chemistry concepts was good and sufficient. Very good comprehension only belongs to a few students.
TABLE I. MICROSCOPIC COMPREHENSION OF CHEMISTRY EDUCATION STUDENTS

\begin{tabular}{|c|c|c|c|c|c|}
\hline \multirow{2}{*}{$\begin{array}{c}\text { Comprehension } \\
\text { Categories }\end{array}$} & \multicolumn{5}{|c|}{ Years of -(\%) } \\
\cline { 2 - 6 } & $\mathbf{4}$ & $\mathbf{3}$ & $\mathbf{2}$ & $\mathbf{1}$ & Mean \\
\hline Very Good & 11,5 & 12,5 & 7,4 & 4,7 & 9,0 \\
\hline Good & 62,8 & 51,5 & 47,7 & 35,3 & 49,3 \\
\hline Sufficient & 25,6 & 36,0 & 44,9 & 58,5 & 41,3 \\
\hline Poor & 0 & 0 & 0 & 1,5 & 0,4 \\
\hline Very Poor & 0 & 0 & 0 & 0 & 0 \\
\hline
\end{tabular}

Source: Raw Data Analysis

\section{B. Multiple Intelligences of Chemistry Education Students}

Below is the data of multiple intelligences of Chemistry Education Students.

TABLE II. DOMINANT INTELLIGENCE OF CHEMISTRY EDUCATION STUDENTS

\begin{tabular}{|l|l|l|l|l|l|}
\hline \multirow{2}{*}{\begin{tabular}{c}
\multirow{2}{*}{$\begin{array}{c}\text { Type of } \\
\text { Intelligence }\end{array}$} \\
\cline { 2 - 6 }
\end{tabular}} & \multicolumn{5}{|c|}{ Year of- (\%) } \\
\hline Linguistic & 1,3 & 3 & $\mathbf{2}$ & \multicolumn{1}{|c|}{ Mean } \\
\hline $\begin{array}{l}\text { Mathematical } \\
\text { Logic }\end{array}$ & 1,3 & 6,2 & 2,9 & 1,5 & 2,98 \\
\hline Visual Spatial & 5,1 & 3,1 & 5,9 & 1,5 & 3,90 \\
\hline Interpersonal* & 20,5 & 30,1 & 28,0 & 17,5 & 24,03 \\
\hline Intrapersonal* & 44,9 & 39,1 & 27,9 & 45,6 & 39,38 \\
\hline Kinesthetic* & 9,0 & 17,2 & 11,8 & 10,3 & 12,08 \\
\hline Music & 3,9 & 6,2 & 10,3 & 0,0 & 5,10 \\
\hline Naturalistic* & 14,1 & 11,0 & 14,5 & 23,5 & 15,78 \\
\hline
\end{tabular}

The most dominant multiple intelligences belong to chemistry education students are intrapersonal, interpersonal, naturalistic and kinesthetic. On the contrary, the least dominant multiple intelligences are linguistics and mathematical logic.

\section{Learning style of Chemistry education students}

Identification of students learning style produce the data shown in Table 3 below.

TABLE III. LEARNING STYLE OF CHEMISTRY EDUCATION STUDENTS

\begin{tabular}{|c|c|c|c|c|}
\hline \multirow{2}{*}{ Learning Style } & \multicolumn{4}{|c|}{ Year of -(\%) } \\
\cline { 2 - 5 } & $\mathbf{4}$ & $\mathbf{3}$ & $\mathbf{2}$ & $\mathbf{1}$ \\
\hline Auditorial & 41,0 & 50 & 45 & 47 \\
\hline Kinesthetic & 29,5 & 35 & 29 & 41 \\
\hline Visual & 29,5 & 15 & 26 & 12 \\
\hline
\end{tabular}

Learning styles owned by most Chemical Education students are auditory and kinesthetic. It means that most students tend to prefer learning by listening and physical activities rather than reading.

\section{Relationship between Multiple Intelligences and Microscopic Comprehension}

Statistical correlation between multiple intelligence and microscopic comprehension using SPSS 15 generates sig. (Pvalue) between the two data is $0.000(<0.05)$, with a correlation coefficient of 0.612 . It means there is a positive correlation 
between variables of multiple intelligences and microscopic comprehension by the correlation coefficient of 0.612 . In other words, if multiple intelligence increases, microscopic comprehension will also increase. The coefficient of determination 0.375 indicates that multiple intelligences contributed $37.5 \%$ of increasing students' microscopic comprehension. The $62.5 \%$ mastery of concepts is influenced by other factors.

The statistical correlation test between three learning styles and microscopic comprehension using SPSS 15 generates various results. There is a weak correlation between visual learning style and students' microscopic comprehension. For auditory learning styles, the correlation coefficient is lower than visual learning style, but the p-value shows that relationship between auditory learning style and students' microscopic comprehension still exists. Analysis of kinesthetic learning style indicates that there is no relationship between kinesthetic learning style and students' microscopic comprehension. Thus, of the three learning styles, only visual and auditory learning styles are associated with students' microscopic comprehension.

\section{E. Discussion}

The identification of students' microscopic comprehension showed that the microscopic comprehension of chemical education students ranged from good $(49.3 \%)$ to good enough $(41.3 \%)$. Only a small part of students' comprehension is categorized as "enough". Poor understanding possessed only $1.5 \%$ of first-year students.

Difficulties in the understanding of microscopic concept happen on 2 of the 3 evaluated concepts, namely chemical bonding and the acid-base equilibrium concepts. Even though the comprehension of the acid-base concept is corrected, but from 5 acid-base questioned problems there are three concepts that are still misunderstood. That is the strength of acids and bases concept and the acid-base conjugation of Bronsted Lowry concept. Students' microscopic comprehension is very important because according to [8], students' difficulties in understanding microscopic concept may cause incorrect understanding of potential in causing misconceptions. The importance of microscopic concept understanding was realized by [9] in his research. He found that to understand chemistry concepts is not enough using the macroscopic concept only, but also need a microscopic comprehension.

In case of multiple intelligences, the most dominant intelligences are intrapersonal, interpersonal, naturalistic, and kinesthetic. On the contrary, the least dominant intelligence is linguistics and mathematical logic. Ironically, most of the schools implement the lecture method which tends to rely on linguistic intelligence and logic capabilities. This finding is similar to the research result conducted by [10] in the middle and high school students in Banjarmasin, Indonesia. These four intelligences are types of intelligence which are generally owned by students from the age of 13 to 20. Ref. [10] also found that basically there is a relationship between multiple intelligences and ages in low-level correlation. It means, multiple intelligences of a person can only be associated with age, but it is not necessary since multiple intelligences is not only influenced by age, but also by other factors such as genetics, environment, and nutrition [11]. A teenage life that is mostly used for socializing, connecting with others, realizing the importance of self-existence in association peers causes interpersonal, intrapersonal and kinesthetic intelligence develop in their teens [12]. In addition, the social environment among students causes naturalist intelligence improve better.

These findings have implications for teaching methods that should be used in lectures. Since mathematical logic and linguistics intelligence are low; on the contrary, interpersonal, intrapersonal, kinesthetic, and naturalist intelligence are high. Then, more serious efforts of the lecturers to improve mathematical logic intelligence by using learning strategies that can develop mathematical logic such as discovery, find patterns of events and classification system are needed.

To improve linguistic intelligence, the lecturer should apply specific instructional strategies such as storytelling, reading, writing scientific work, or debate [7]. By implementing these strategies, it is expected that linguistic intelligence could improve better. However, on the other side, the lecturer should also use other learning strategies in accordance with the most dominant intelligence of students such as hands-on activity, mentoring, group discussion, self -reflection, selfassessment, and field studies for the four types of intelligence possessed by most students [7]. Viewed from learning style, most students have auditory $(47 \%)$ and kinesthetic $(41 \%)$ learning styles. In other words, students would prefer to learn by listening and moving on rather than reading. These data are relevant when viewed from the type of multiple intelligences belongs to most students such as intrapersonal, interpersonal and kinesthetic. Those who have auditory learning style tend to be more rapidly understand some information by listening and remembering what was discussed rather than what was viewed, good in speaking and storytelling, explain anything widely, cannot be quiet for a long time, and like doing the cooperative task [1].These characters are similar to the character that belongs to those who have multiple intelligences as formulated by [2] and [7].

Analysis of the relationship between intelligence and microscopic comprehension compound showed a significant correlation with a correlation coefficient of 0.612 . It shows that outside of the type of intelligences, the higher the multiple intelligences, and the better of the students' microscopic comprehension. The results of this study are similar to the findings of research conducted by [9] which showed a significant positive relationship between multiple intelligences and the conceptual understanding of chemical thermodynamics and physics. Ref. [2] stated that the human intelligence is the ability to create and solve problems. Thus, the higher the person's intelligence compound is the higher the person's ability to solve problems, including problems related to subjects such as the completion of assignments, exam questions, and others.

The analysis of the relationship between learning style and a microscopic comprehension showed there is a significant positive correlation between visual learning styles together with auditory learning styles and a microscopic comprehension of the concept with a low correlation coefficient. This result is relevant to researchers conducted by [13] and [14] who found 
that there is a significant relationship between the different learning styles and the student performance. Learning styles support students' performance, especially in learning the specific subject such as English and Chemistry. On the contrary, there is no relationship between kinesthetic learning style and microscopic comprehension. These findings are a bit contradictory with the results of research conducted by [15] as well as research [4]. Ref. [15] found that it was no correlation between learning styles and academic achievement history, while [4] revealed that a strong relationship between the three styles of learning with student achievement in mathematics. Yet, this is understandable because there are considerable differences between the character of a history lesson, mathematics, and english with chemical subjects mainly related to the microscopic comprehension of the concept. More microscopic comprehension requires the ability to imagine visually, so it is irrelevant if in this study visual learning style is more related to the ability of microscopic comprehension. Unfortunately, the percentage of chemistry education students who have a visual learning style is even less than the two other learning styles. The implication of this research is a lecturer needs to identify students' learning styles and adjust teaching methods to the learning styles of most students. It was also necessary that efforts be made to help students enjoy their visual learning style by using audio-visual media when teaching of microscopic concepts.

\section{CONCLUSION}

Based on the results of the study, it can be concluded that: (1) Students' comprehension toward microscopic concepts of acid base, chemical bonding, and chemical equilibrium were categorized as good and sufficient, (2) Most of the students have dominant intelligences on intrapersonal, interpersonal, naturalist and kinesthetic. Very few students have dominant intelligence on linguistic and mathematical logic, (3) Most of the students have auditory and kinesthetic learning styles. (4) There is a positive relationship significantly between multiple intelligence and microscopic comprehension ability, (5) there is a relationship between visual together with auditory learning styles and microscopic comprehension conceptual. (6) There is a relationship between kinesthetic learning style and microscopic comprehension conceptual.

\section{REFERENCES}

[1] Rita Dunn; Kenneth Dunn., Teaching Secondary Students Through Their Individual Learning Styles, Massachuset: Allyn and Bacon, 1993.

[2] H. Gardner, Multiple Intelligences, New York: Basic Books Hons of Learning arper Collins Publ. Inc., 1993.

[3] Nurbaeti., "Hubungan Antara Gaya Belajar Dengan Prestasi Belajar Kimia Siswa Kelas XI IPA Semester II M.A. Ali Maksum Yogyakarta 2007/2008.," [Online]. Available: http://digiib.uinhttp://digiib.uinsuka.ac.id/2555/2.. [Accessed 17 March 2016].

[4] N. D. Lutfita, "Pengaruh Gaya Belajar Siswa Terhadap Prestasi Belajar Matematika di SMP Negeri 1 Ngunut. Laporan Penelitian.," [Online]. Available: http://repo.iain-tulungagung.ac.id/. [Accessed 17 Maret 2017].

[5] Husni, Kamaluddin; Kade A., "Hubungan Antara Kecerdasan Majemuk Dengan Hasil Belajar Fisika Siswa Kelas VII SMP Negeri di Kota Palu.," Jurnal Pendidikan Fisika Tadulako (JPFT), vol. 1, no. 3, 2014.

[6] Handoko, Z. P.; Wrastari, A. T, "Hubungan antara Gaya Belajar dengan Metode Pengajaran Guru SMA di Kawasan Surabaya.," Jurnal Psikologi Klinis dan Kesehatan Mental, vol. 3, no. 2, 2014.

[7] T. Armstrong, Multiple Intelligences in the classroom, Virginia: Association for Supervision and Curriculum Development (ASCD), 2004.

[8] Nakhleh, "Student Model Matter in the Cntext of Acid Base Chemistry," Journal of Chemical Education, vol. 71, no. 6, pp. 495-499, 1994.

[9] R. Leinonen, .; Asikainen, M. A.; Hirvonen, P. E., "Grasping the Second Law of Thermodynamics at University: The Consistency of Macroscopic and Microscopic Explanations.," Physical Review Special Topics Physics Education Research, vol. 11, no. 2, pp. 020122-1-02012, 2015.

[10] A. Winarti, "The Multiple Intelligences of Junior and Senior High School Students in Banjarmasin and Its Relationship with Age and Gender," in Conference Proceeding of Science Education National Seminar Held by Post Graduate of Science Education Department UNESA, Surabaya, 2015.

[11] J. Rakhmat, Belajar Cerdas: Belajar Berbasiskan Otak, Bandung: MIzan Media Utama, 2010

[12] J. W. Santrock, Educational Psychologi 2nd Edition., Dallas: Mc Graw Hill Co, 2004.

[13] Soghra, A. C.; Ali G.; Mohammad, G. T., "Learning Styles and Academic Performance of Students in English as A second Language Class in Iran," Bulgarian Journal of Science and Educational Policy, vol. 7, no. 2, pp. 322-333, 2013.

[14] Marzieh K. ; Khalil M..; Hamid, A., "The Relationship between Iranian EFL Instructors' Understanding of Learning Styles and Their Students' Success in Reading Comprehension," English Language Teac, vol. 6, no. 4, pp. 134-142, 2013.

[15] A. S Johari.; Ahmad, A., "The Relationship Between Learning Style And Student Achievement In History Subject," IOSR Journal Of Humanities And Social Science (IOSR-JHSS), vol. 21, no. 7 ver III, pp. 07-14, 2016. 